on the strength of the Bill introduced into the House last year, "whole hosts of men flocked to Aberdeen and St. Andrew's for degrees, expecting by those easily-obtained diplomas to be admitted into the London College." But this objection will not apply to Edinburgh graduates, as the number of gentlemen who took their degrees there last year was at least one-half less than usual. Why, in the name of fortune, not admit all British M.D.'s who have completed their twenty-sixth year, without examination, and on paying a reduced fee? That would be at once fair, honourable, and conciliatory. But at the very least, all Edinburgh graduates and fellows of the Edinburgh College of Physicians, twenty-six years of age, ought, undonbtedly, to be so admitted, should they wish it.

I hope, Sir, you will kindly consider this point in your place in Parliament, and also publish this note in your next number, that the above exclusive and insulting rule may be resisted in time. Yours respectfully,

May 17, 1845.

M.D. EDIN.

\section{THE "ONE PORTAL" OF THE PROFESSION.} To the Editor of THE LANCET.

Sir,-The Right Honourable the Secretary of State for the Home Department professes to be anxious that all should enter the medical profession through one portal, and in the Bill about to be again submitted to the consideration of Parliament, he has introduced a most objectionable provision to secure that object; but if he had consulted the public safety, he would have made that entrance through the portal of the general practitioners. Nature draws no distinetion between medicine and surgery; and before a man should be permitted to practise a part of his profession, he ought to be compelled to make himself master of the whole. Then, and not till then, may he be safely allowed to practise whatsoever braneh of it his inclination or his cireumstances may determine; and then, also, if 'he covet the distinction of " a pure surgeon or a pure physician," in the name of all that is puerile, let him enjoy it.

I have called Sir James Graham's provision a most objectionable one, bat it is much more than that; it is most degrading and most odious, for it renders it imperative upon every one wishing to enter the medical profession, first to obtain the permission, consent, or "liceat" as it is smoothly termed, of a set of semi. qualified monopolists, directly opposed to the respectability and interests of the general practitioner. But even if that were not the case, the proposition is in itself so monstrous, so gross a violation of the liberty of the subject, that it caunot be contemplated but with united feelings of indignation and disgust. What! Is it come to this? Must an Englishman ask permission to make the science of medicine his study and profession? Apply the same regulation to law, to divinity, or to any other pursuit, and its tyrannical eharacter will become at once self-evident. Most emphatically and most solemnly, do I protest against sueh an enormity; and most earnestly do I entreat you, both in the house and out of the house, to raise your voiee against it.-I have the honour to remain, Sir, yours very respectfully,

Stowmarket, May 24th, 1845 . J. Bedingrexd.

\section{DUTY OF THE MEMBERS OF THE COLLEGE TOWARDS THAT INSTITUTION. \\ To. the Editor of THE LANCET.}

Srr,-Having sent my name, together with the names of some of my professional neighbours, for enrolment in the list of the Association of General Practitioners in Medicine, Surgery, and Midwifery, in the hope that so large a body as the Association now numbers would, by expressing its determination to use every legitimate means in its power, induce the Council of the College of Surgeons to acquiesce in its wishes; and finding, that instead of this most desirable issue, the College itself is to be at once abandoned by its present, and those who would become its future members, by the setting up of some new institution in opposition to it, I have this day addressed a note to Messrs. Bird and Ancell, requesting them to erase my name from the list of the Association.

To avoid the charge of inconsistency, $I$ beg to state some of my reasons for so doing: First-Until it was announced by the Committee, " that, from the outset, it had been their intention to obtain a separate corporation," I had entertained a hope (as stated above) that an adjustment would be brought abont between the Council and the members of the College. Secondly-I would beg to remind the members of the College, collectively and individually, of the oath which they and I took and subscribed our names to when we were admitted.

The oath coneludes thus, " and, to the utmost of your power, maintain the dignity and welfare of the College- so help you God." Now, notwithstanding the Council of the College have, by their recent charter, inflicted so much injustice on the great body of its members as to furnish them with "a reasonable ex. cuse for resisting their ordinances," (another part of the above oath, ) it by no means follows that the members are to desert the institution, the dignity and welfare of which they have sworn to maintain to the utmost of their power.

Most respectfully and earnestly do $I$ entreat every member of the College to bear in mind this oath which he has taken. In joining to set up a new College, we should not only virtually, but actually, violate this sacred obligation, by doing that which (if carried into effect) must eventually be the ruin of the present College, to which we belong, and we should justly be taunted by the whole world for our perfidy.

The general practitioners must ever constitute the great bulk of the profession in this kingdom-if, therefore, a new establishment is to be raised, how is it to be supported but by the fees paid by its future members? And how, then, I would ask, is the present College to be kept up, and what is to become of its unrivalled museum and library, together with all the benefits it is capable of diffusing amongst its members, for the public good?

Although as a member of the College of Surgeons I feel that I am degraded and insulted by the recent Charter, and no less so by the scandalous manifesto of the Council, nevertheless, I feel that nothing can absolve me from the oath which I took when admitted. In conclusion, permit me to add that $I$ am ready to join in any scheme for resening the College from its present untoward position, yet I will never voluntarily sever myself from it, nor knowingly do that which may contribute (if followed by others) to degrade that noble institution.

Most cordially thanking you for your long and unwearied exertions for the real welfare of the profession, and of the general practitioner in particular, I remain, Sir,

Honiton, May 26 th, 1845. Your obedient and obliged servant, J. C. JERRARD,

\section{OPINIONS OF THE PROFESSTON ON MEDICAL LEGISLATION.}

To the Editor of THE LANCET.

Srr,-Lest the Hanover-square-room Committee should construe silence into approval of their proceedings, it would be advisable for provincial practitioners to break it. How is this to be accomplished? There cannot be a doubt that all are deeply anxious respecting the present state of affairs. Two matters agitate the medical world:-1st, That of separate incerporation of general practitioners; 2ndly, Their enfranchisement in the College of Surgeons.

Have these questions been put to the country practitioners? No. They have been harassed with "reports," and perplexed with paltry questions; but their deliberate opinion on these two main questions has not been obtained. Then how can it be $\theta b-$ tained? Their pressing duties will not suffer the mass to visit the metropolis, therefore an earnest, brief, simple appeal, by circular, should be made to the members of the profession, calling upon them to express their approval, by a monosyllable, either for a separate incorporation or enfranchisement in the college. The result must be decisive in character.-Yours, \&c., Stamford, May 26 th, 1845 . Charles Srmpson, M.R.C.S.L. \& L.A.C.

* * Although the members of the profession cannot express their opinions personally at any-meeting or meetings in London, yet they may fully and effectually accomplish the object described by our correspondent, by means of a system of district representation; a system that ought to be adopted in electing the CONFERENCE.

\section{THE AMENDED BILL AND THE APOTHECARY- CHARTER. \\ To the Editor of THE LANCET.}

SrR,-Permit me to make a few remarks on matters connected with the amended Medical Bill and proposed new Charter, and the commentaries upon them contained in ThE LANCET. In my humble opinion, no man, whether the Editor of any medical periadical, or any other person, has rendered services for the reformation of our medical and surgical corporations, and the management of our magnificent public medical institutions, at all approximating, in value and importance, to those rendered by yourself, and promulgated, and, as far as possible, reduced to practice, through the medium of THE LANCET. And.although your leading articks have occasionally been very stringent and awakening, yet.they have not been more so than the frailties of human nature, and 
their incidental evils-corruption, fraud, and tyranny, have demanded.

'As for "GaLLIPot LodGe" and the committee of seventy-two, one would have supposed that the "visitations" they have received from THE LANCEN would have produced a salutary inflnence upon their consciences, and caused them to retrace their steps into paths of honour, probity, and even-handed dealing. Yet, notwithstanding the mighty interests at stake, the irresponsible and cabalistical " 72 " are still prostrating them for the purposes of self-aggrandisement, and the retention of personal authority. They have indeed acquired "a bad eminence;" a body now acknowledged throughout the length and breadth of England with derision.

Sound are your views respecting the College of Surgeons being made the "home and head" of the general practitioners of England and Wales, and failing which any new college should be placed upon a perfect footing of equality with it. Too plain is it that "GALLIPOT LODGE" is intended to be only a "Lodge" to the two superior colleges, by the servile and cowardly committee of Hanover-square.

It has been said that "those whom the gods intend to ruin they first infatuate." If the Council of the College of Surgeons be resolved to refuse as allies and friends the general practitioners of Englanid, never was the declaration more truly illustrated; and the acceptance of the amended Medical Bill by the Hanoversquare Committee deserves a similar application of the remark to them.

Whilst writing this letter, the post has brought me the "Transactions of the National Association." Even the supple committee has some qualms respecting it, for almost the first sentence which attraets notice is this:- "Nevertheless, the committee regret to say their approbation of the measure is not unalloyed." The general practitioners of England, they may be assured, cordially and deeply sympathize with them on this one point.

By way of conclusion, permit me to observe, that the Committee of Seventy-two and the A pothecaries' Company, in their correspondence with each other, forcibly brings to mind the following illustration :- " Two brothers commenced business, one in London, whose name was PIG; the other in Halifax, whose name was BACON. Pig had an engagement to meet, and drew a bill upon Bacon, which the latter accepted. Bacon having an engagement to meet, drew a bill upon Pig, which the latter accepted. But it appeared that Messrs. P. and B. were secretly in partnership,-in other words, theirs was "one concern." What sort of a hold upon the acceptors had the unfortunate creditors when the two bills became due, and both were returned dishonoured? The partners had got cash for both bills, and the holders received sixpence in the pound from the two estates that were one.

$I$ an, Sir, your obedient servant,

Hebden Bridge, near Halifax, May 26 th, 1845.

ROBERT HOWARD.

\section{"THE TIMES" ON "DISUNION."}

To the Editor of ThE LANCET.

SIR,-In the name of all that is just and prudent, what does "The Times" mean by constantly exhorting that there may be "no-disunion" amongst us. What! Are we not to repudiate a Commitree of seventy-two, which has almost destroyed our canse, and having no laws for its government, we cannot bring it to account, or shake it off. There must be disunion, or we shall all be betrayed and ruined. I am, Sir,

Greenwich, May 2gth. Yours obediently and thankfully, AN ENGLISH Surgeon.

\section{THE FUNDS OF THE COLLEGE.}

To the Editor of THE LANCET.

Srr, - The spirit moves me to offer a few thoughts, which may not have occurred to others, and thus lend my humble aid to induce members of the Royal College of Surgeons to place things in their proper light, and call things by their right names. Is it not a fact, by whatever means we may endeavour to avoid seeing it as such, that every member of the College of Surgeons, whose name has been left out of the list of Fellows, is now virtually turned out, and deprived of that which he before possessed, although but a name; still we were allowed to be called surgeons. Some of us considered this an honour, until our eyes were opened by the late astounding manifesto of the Council of the College; before that appeared, we considered we had done something, by days, and nights, of anxious study and toil, to make ourselves acquainted with our professional dnties; and to give ourselves and the public confidence, we underwent our examinations, and received a diploma, stating we were competent to act as surgeons.
Many of us have thas been induced, by our timely aid, to stand between the living and the dead, by performing operations which are termed capital-by judicious aid in critical cases of childbirth, when miles from any second opinion. By whom are we thus deprived of our name, for now we see plainly it was never intended for any other by men, many of whose names have never appeared either in surgery or science.

The object of my letter is to propose. that as we are now virtually turned out of the College of Surgeons, and, by the Bill, we are to be deprived of that which, it appears, we only before possessed, the name of "surgeons," that the Council be requested to refund the money, (£22) with interest, if they can afford it; as it appears, by their own showing, in this ever-to-beremembered manifesto, was received under false pretences, If, then, after every trial, we are obliged to fall back into a lower grade than we have occupied, let the members join in returning their now worthless diplomas, and demanding a return of their money; and surely we might, with the manifesto in our hands, stand some chance in a court of law to recover it.

Epsom, May 24th, 1845.

I am, Sir, your obedient servant, George Stilwell.

\section{MR. BRAID ON HYPNOTISM.}

To the Editor of THE LANCET.

SIR,-I accept of your offer to publish even "a few lines," to enable me to point out briefly wherein my opinions, on several points, have been given by Dr. Hall in a manner calculated to convey very erroneous impressions. of $m y$ views of the nature and extent of mesmeric phenomena. - It might not have been so intended by Dr. Hall, but the manner in which he introduced my name in $\$ 47$, coming as it did immediately after a collocation of all the extreme views of the ultra mesmerists, about clairvoyance and all the "higher phenomena," as they are styledwithout a single qualifying remark to the contrary-was naturally calculated to impress your readers with the notion that I gave in my adhesion to all these extreme views.

Dr. Hall well knows that I adopted the term "hypnotism" to prevent my being confounded with those who entertain these extreme notions, as well as to get rid of the erroneous theory about a magnetic fluid, or exoteric influence of any description. being the cause of the sleep. I distinctly arowed that hypnotism laid no claim to produce any phenomena which were not " quite reconcilable with well-established physiological and psychological principles;" pointed out various sources of fallacy which might have misled the mesmerists; was the first to give a public explanation of the trick by which Mr. Hewes' lad "Jack"-referred to by Dr. Hall-contrived to deceive his master, and impose upon the public in Greenwich, London, Manchester, and elsewhere; and that I stated, at my conversazione at the Manchester Royal Institution, in April, 1844, in reference to clairvoymuce and the alleged irresistible power of the mesmeriser's will over his subjects, " to me it appears far more probable that the narrators have been deceived, than that the Almighty would ever delegate to man such dangerous prerogatives and powerspowers which are quite inconsistent with the security and harmony of society in the present state of our existence."

Again: my remarks about the influence of imagination are referred to in such a manner as might lead to the belief that I was a supporter of the imagination theory - $-i$. e., that the induction of the sleep in the first instance is merely the result of imagination. My belief is quite the contrary. I attribute it to the induction of a habit of intense abstraction, or concentration of attention, and maintain that it is most readily induced by causing the patient to fix his thoughts and sight on an object, and suppress his respiration. That besides mental influence, the biood is thus ineficiently oxygenated, and this creates a disposition to sleep in the first instance. A repetition of the process renders the subject more and more susceptible, through the well-known law of habit and association coming into play, and thus many become so susceptible as to be liable to be affected entirely through the imagination, sympathy, and habit, and will be affected or not affected by the same process, or by no process at all, according to their expectation or belief. However, I have never seen such a result as this take place, unless in patients who had been previously hypnotized or mesmerized.

The only other point to which I shall advert is phreno-mesmerism. The views for which I have contended on this point are not at all comprehensible from Dr. Hall's papers, and might lead to the supposition that I hold the manifestations educed in this manner as conclusive evidence of the correctness of the organology of phrenologists, whereas I have distinctly maintained that they neither prove nor disprove the doctrines of phrenology, but, for reasons which I have fully explained elsewhere, that they leave that question precisely where they found $i$. I attribute the phenomena 